\title{
Double-trouble: Negotiating Gender and Sexuality in Post-colonial Women's Rugby in Fiji
}

Women's marginalisation in sports has attracted growing research attention since the 1980s. Surveying this literature, Kleindienst-Cachay and Heckemeyer (2008) identify two main currents of thought: 1980s and early 1990s research viewed sport primarily as a site for the (re)production of hegemonic masculinity and highlighted persisting mechanisms of women’s marginalisation (e.g., Hargreaves, 1986; Birrell and Cole, 1990; Wright and Clarke, 1999); by contrast, post-mid 1990s contributions tend to discuss women's increased participation as a challenge to the male preserve and a gradual dissolution of gender boundaries (e.g., Hargreaves, 1997; Scraton, Fasting, Pfister and Bunuel, 1999). Women athletes' responses to gender and hetero-normativity have also attracted research attention, with reference to the "female apologetic" (Felshin, 1974; Griffin, 1998). While some have studied women's displays of normative femininity and heterosexuality to compensate for their masculine sport and/or body (e.g., Caudwell, 1999; Cahn, 1994; Scraton et al., 1999; Watson, 1987; Mennesson, 2000), others have highlighted instances of athletes' unapologetic defiance peppered with masculine-and-proud attitudes (e.g., Broad, 2001; Sabo, 1993).

These views are echoed in existing research on rugby union, which has been studied extensively as a platform of hegemonic masculinity and hetero-normativity (Dunning, 1994; Wheatley, 1994; Nauright and Chandler, 1996). Women's 'trespassing' to this sport has also been documented, often with attention to the question of the female apologetic. Carle and Nauright (1999) observe that the Australian women players studied emulate male rugby culture and simultaneously conform to male expectations of femininity. Fallon and Jome (2007) explain this as a "gender-role conflict”. Similarly, Tovia (2014, n.p.) discusses New Zealand women players' dilemma of managing “the tension of playing to the ideal image of a rugby player on the field and maintaining their femininity after the game.”

Other researchers focus more on the oppositional, unapologetic elements of women's rugby. Wheatley (1994) studied the discourses on sexuality underlying American women's rugby songs as a challenge to male heterosexual hegemony. Chase (2006) explores American women rugby players' resistance to discourses of the ideal feminine body, while Gill (2007) discusses British women's use of the sport's inherent violence to redefine femininity. Hardy (2014) similarly observes that the Canadian women 
players in her study reject apologetic behaviour despite being surrounded by media images promoting it. The most evidently oppositional interpretation is offered by Broad (2001), who sees an American women's rugby club as a site of "queer resistance” consisting of gender transgression, destabilisation of the heterosexual/homosexual binary, and "in your face" confrontations of stigma.

While this body of literature has shed significant light on women's experience and use of rugby, it is almost entirely based on research undertaken in Western contexts. In this paper, we move away from Western-centrism by focusing on women's rugby in Fiji. The historical, socio-cultural and political specificities of the postcolonial society add a further, so far largely unexplored, dimension to the nexus of sport, gender, sexuality and power. In particular, as we show in the following sections, indigenous hegemonic masculinity and masculinism in Fiji, with rugby as its primary cultural expression, is profoundly articulated with, and doubly entrenched by, anti-colonial ethno-nationalism. We intend to explore Fijian women athletes' experiences of and responses to such "double trouble" in the postcolonial context. Furthermore, in an attempt to contribute to a growing body of literature that looks into the complex interplay between women rugby players' opposition to and accommodation of gender structures (e.g., Adjepong, 2015; Ezzell, 2009), we intend to examine the sport in Fiji as a contested site of hegemonic struggle, that is, domination, resistance as well as negotiation.

Fijian women have played rugby in an organised fashion at least since the late 1980s. By 1999/2000 they had established about six clubs in Suva, with little external support. The Fiji Women's Rugby Union (FWRU) was established in 2006 (World Rugby, 2007). The development of the sport over the past decades is solely attributed to the determination and sacrifice of the players, coaches and supporters who organised and financed their own activities. As of 2015, there are five clubs in Suva affiliated with the FWRU, and up to 10 clubs/teams are emerging elsewhere. The player population is miniscule compared to that of men's rugby. World Rugby statistics show 270 senior female players and 100 teen players (IRB, 2012). The majority are indigenous Fijian, in their twenties, transmasculine and lesbian/gay, while some may be female-to-male transgender and there are a small number of cisgender and heterosexual athletes. Many are unemployed and with limited formal education, although some are in skilled employment or in tertiary education. In the following sections, we explore the lived experiences and voices of these rugby players, guided by the research question: "How do Fijian women players experience and respond to gender and hetero-normativity 
enforced by and through rugby in its specific postcolonial context?”

Our discussion is informed primarily by Antonio Gramsci’s (1971) concept of hegemony, which illuminates how relations of power are both maintained and contested through the medium of ideological and cultural struggle. The strength of the Gramscian scheme is its attention to the dynamic interplay between forces of domination and resistance. This broad theoretical perspective will be complemented by Postcolonial Feminism, especially its problematising of the implicit ethnocentrism and universalism in Western (feminist) scholarship (Mohanty, 1988; Spivak, 1988). The critique presented decades ago remains relevant in much contemporary sport literature that falls short of taking full account of non-Western women's multiple experiences, voices and agency in their local contexts. These can make meaningful contributions to the existing literature on women's participation in male-dominated sports.

\section{Method and Methodology}

The study employed a semi-structured interview research design. The primary data were collected between August 2012 and July 2014 through interviews with ten women players and three officials ${ }^{1}$ (two of whom were interviewed twice) and informal conversations with the interviewees and other players. The interviewees were recruited via the snowball sampling method. Efforts were made to maximise the diversity of the sample by including players from all of the women's rugby clubs in Suva (the capital) and players of diverse backgrounds (especially in terms of age, employment and education). Eight interviewees were open with their sexuality and identified as lesbian/gay, either during or outside of the interviews. Nine were in their twenties, and four in their thirties. Eight had played rugby for over 5 years, four played for 3 to 5 years, and one was new to the game, only playing for a year. Nine were in employment in various fields and four were not employed. The interviews were conducted by the first author in English at the times and places chosen by the interviewees, often at training grounds, the gym that the interviewees used and their homes. They were audio-recorded with the interviewees' permission, transcribed and put to qualitative, thematic coding guided by the research questions above and new insights emerging from the data. The analysis consisted of the transcripts repeatedly read by both researchers to achieve further familiarization with the data. Independently, each author identified raw data themes which were then extensively discussed until agreement was achieved on all themes (see Butt and Molnar, 2009). Additionally, 
non-participant observation by the first author provided information that supplemented the interview data and analysis.

In the following sections, quotations from the interview data are presented as indented, italicised paragraphs or indicated with inverted commas in the main text. The participants and athletes are referred to as "women" and "women athletes/players" because the majority of them are transmasculine women (i.e., they identify themselves as women), and additionally, their experiences of the hegemonic gender block are primarily shaped by their socially-assigned status as women.

The research process was informed by feminist methodological insights (see, Reinharz, 1992; Sprague, 2005; Doucet and Mauthner, 2006), especially in relation to the researcher-participant relationship. In contrast with the conventional emphasis on impersonality and detachment, many feminist researchers regard interviews as guided conversations, aimed at faithful representation and appreciation of participants' multiple voices and experiences. Participants hence exercise greater freedom to shape the course of the conversation, which widens the scope of information obtained and mitigates theory imposition. Furthermore, critical of the conventional interview model that disregards the power differentials between the researcher and the researched, many feminists call for genuine mutual trust and rapport developed through a sustained, personal and reciprocal researcher-participant relationship.

These insights guided the research relationship in this study. Both authors are active supporters of women's rugby in Fiji, with the first author, who undertook the interviews, directly involved in advocating for the sport and local clubs. She attended local rugby tournaments, games and training sessions and developed friendships with a number of athletes before the study commenced, when the authors were confident that a mutually trusting relationship had begun to be developed. Efforts were made to keep the interview/study a mutually meaningful process, although this by no means cancelled the power inequity inherent in the research relationship.

\section{Rugby, gender, sexuality and collective identity}

Fiji is a Pacific island nation with a population of approximately 837,271, consisting largely of indigenous Fijians and Indo-Fijians (Fiji Bureau of Statistics, 2015a).

Although this former British colony (from 1874 to 1970) is regarded as one of the more developed countries in the region, its economy has been grappling with economic 
challanges. In fact, official statistics show that almost a third of the population lives in poverty (Fiji Bureau of Statistics, 2015b). The economic strife of the nation is partly attributed to long periods of political instability, including four coups d'état between 1987 and 2006. Constitutional rule was restored only in 2014.

Rugby union has played a conspicuous socio-cultural role in this postcolonial context. It is often described as Fiji's "national” sport, with an estimated 60,000 predominantly male players (FRU, 2011). It is regularly voiced that "rugby has placed Fiji on the world map” (Nasokia, 2014). The national rugby sevens side is particularly successful, having won the prestigious Hong Kong Sevens tournament a record 15 times. Elite Fijian players are in high demand in metropolitan countries (Kanemasu and Molnar, 2013a). Such international prominence is widely associated with national pride, aspirations and identity. Rugby's significance in the construction of a sense of nationhood can be seen in the Prime Minister, Voreqe Bainimarama's statement upon enforcing a decree requiring the 2014/15 HSBC Sevens World Series coverage to be shared across television channels: "I'm not interested in anything other than giving every Fijian ... the right to see our national team - the pride of our nation - compete on the international stage” (Field, 2015, italics added).

While sports in general have been shown to be deeply implicated in national identity-making (Bairner, 2001), rugby’s symbolic role in Fiji has a notable anti-colonial dimension. In the face of the prevalent Western notion of Pacific island nations as decidedly peripheral - i.e., small, poorly-resourced and dependent on Western assistance for survival (Hau'ofa, 1993) - rugby has served as a medium of symbolic resistance against postcolonial marginality and of asserting an alternative collective self-definition (Kanemasu \& Molnar, 2013a, b). A Fijian diplomat stated recently: “As a Fijian I'm very proud that our [rugby] team with very little resources [sic.] can still compete with the best on the world stage... countries that provide millions of dollars into the preparation of their teams” (Ratuva, 2015). The international success of their rugby players gives an expression to the counter-hegemonic voices of Fijians as a postcolonial people.

This "national” sport has a profoundly gendered and indigenised nature. There exists a dominant, "traditionalist" discourse, both in academic and popular domains, which defines the game as a unique, privileged cultural practice, deeply intertwined with indigenous cultural heritage (Kanemasu and Molnar, 2013c, 2014). Rugby is said to 
embody the essence of indigenous cultural ethos through its embeddedness in the precolonial martial and masculinist traditions, the chiefly system and Christianity. In particular, the precolonial tradition of warfare and masculinism, whereby every male was expected to be a warrior defending their chiefs' territories and interests, is regarded as inseparably fused with the intensely physical, combative and collective nature of the game. Masculinist militarism continues to shape contemporary Fiji, with rugby as its epitome in cultural life (Teaiwa, 2005).

Thus in the context of anti-colonial nationalism, especially at times of international matches, Fijians rally behind the young warriors who put their bodies on the line to fight for the dignity of their small yet powerful rugby nation. Cibi, the war dance performed by the national team, is "our heritage as a nation, a rallying point similar to the National Anthem and a matter of pride for all our people ...to motivate ... Fijian rugby teams, drawing on their warrior instinct" ("Let the war cry be heard”, Fiji Times editorial, 18/11/2009, p. 8). Rugby players are “our heroes” (Narawa, 2013) who proudly display a heavily gendered "Fijianness" and fiercely challenge the postcolonial world order with their rugby prowess.

\section{“Double-colonisation" of women}

Such articulation of masculinism with anti-colonial resistance and identity has been problematic for many indigenous women of the Pacific/Oceania. Māori ${ }^{2}$ feminists, for instance, observe “double-colonisation” of Māori women by larger white New Zealand society and their own men (e.g. Hoskins, 2000). Equally, for indigenous Fijian women, it represents marginalisation by indigenous traditionalism and anti-colonial ethno-nationalism, with rugby serving as a primary symbolic medium of both.

Fiji today remains a profoundly patriarchal society. In the 2013 Gender Gap Index, it was ranked 117th out of 136 countries, dropping from 113rd in 2012, 109th in 2011, and 108th in 2010 (World Economic Forum, 2013). Subordination of women often takes a severe, violent form: 72\% of ever-partnered women have experienced physical/ sexual/emotional violence from their husband/partner (Fiji Women’s Crisis Centre, 2013). Gender relations in indigenous Fijian communities are "influenced by traditional values that emphasise the authority of chiefs ... and the precedence of men before women. Traditional institutions allow women few if any rights to inherit land or formally own property, or to take part in public decision making” (Asian Development Bank, 2006, p. 3). P. Imrana Jalal (2002, p.10-12), a prominent lawyer and feminist in 
Fiji, explains that there is "widespread opposition to any change" to gender relations on the grounds that it is "too "white"” or that "[i]t would destroy the essential nature of Fijian indigenous society”, among others. Vanessa Griffin, another renowned feminist in Fiji, similarly observes: "Culture, or custom, is the commonest argument used against any call for a new image of women in the Pacific. Even aware women are confused about this question because in the postcolonial period, cultural identity is an important part of national rehabilitation and pride” (quoted in dé Ishtar 1994, pp. 218-219).

Related to this is the overbearing prevalence of homophobia and transphobia. As one of our participants explained: "In Fiji, being gay is a big issue... It's to do with the whole values, tradition, culture... Your whole identity gets questioned.” A recent psychological study found intense moral and religious objections to non-normative sexuality in both major ethnic groups, especially indigenous Fijians (Johnson and Vithal, 2015). Homosexual conduct was illegal in Fiji until 2010. Those with non-normative sexual/gender identities continue to suffer daily discrimination and homophobic/transphobic attacks in families, schools, workplaces and communities (McCormick, 2013). One of our participants explained: A lot of [gay] women get beaten up. [One current player] was 17 when she started hanging out with the rugby gang... It was her mother who used to beat her up... She left home and lived with rugby players.

Fijian women's pursuit of rugby should be understood in this specific context. In the following sections we explore their voices and experiences of claiming a sport so heavily steeped in gendered nationalism.

\section{Domination}

Despite modest improvements in institutional support in recent years, ${ }^{3}$ players continue to face a multitude of challenges. They struggle to secure consistent playing schedules, fields, referees, medical support and other facilities/services, and even to meet the most basic needs for jerseys, shoes, appropriate diet or bus fares to reach training grounds. Many players run or walk for miles to training grounds almost every day. The FWRU receives limited FRU funding and fundraises to cover expenses. The Fijiana (women's national team) does not have a consistent corporate sponsor and receives minimal institutional support. As recently as in 2015, the squad members had to fundraise to cover the cost of their own training camp prior to an international tour. They are neither contracted nor medically insured. In other words, the Fijiana and other women play the sport literally at their own risk and expense. They pursue rugby with 'pure passion' and 
against all the odds.

Carle and Nauright (1999, p. 64) observe that combative sports are regarded as "the last true male preserves" and that women who threaten this masculine exclusivity are “symbolically degraded, mocked or vilified.” In Fiji, rugby is not only a pinnacle of masculinity, but a linchpin of indigenous cultural pride and anti-colonial nationalism. Hence reactions to those who infringe this hegemonic masculinist-traditionalist practice are doubly hostile: women athletes have been symbolically and publicly mocked, vilified, sometimes physically degraded and even assaulted.

Women rugby players are commonly associated with sexual/gender variance and severely stigmatised, in parallel with the association between "mannish athleticism" and lesbianism in many societies (Broad, 2001; Cahn, 1994; Wright and Clark, 1999). The players are condemned for (allegedly or actually) being masculine and/or lesbian, and appropriating the cultural practice that enshrines the normative gender and sexual order. They are subjected to marginalisation and at times abuse and ostracism in their families and wider communities. Some families are intensely and sometimes violently hostile to their daughters/sisters playing rugby. The participants recounted many cases of players discouraged or prevented from playing, and beaten or chased out of their homes for non-compliance:

I was training ... and my father found out. And he was unhappy. He stopped me... and he beat me up. So I said, "Okay, I won't go." I was enjoying the sport. I was enjoying the training. You know, men can play the game; I wanted to play too.... But I stopped, until a few years ago.

There was a young woman who was playing rugby, and her brother found out. And he beat her up... When her father came, she was bleeding and everything. The father asked her mum, "What happened?" When the mother told him, he said [to his dauther], "[The beating was]Good for you!"

Some have chosen to leave their family homes to escape disapproval and punishment and stay at friends' or share small lodgings in informal settlements:

They move away from home and stay in one house, especially in squatter settlements. Because in the squatter settlements... it's cheap. So, they're together in 
one home, they do part-time jobs. Some clubs give them small jobs like grass-cutting. But that money, they keep to buy food and pay bills and they walk to the training ground.

Transphobic and homophobic sanction against the players is also pervasive in wider society. The most common instance is the jeering and laughing by game spectators. The participants recounted numerous instances:

We get comments, bad comments. Because of [our] gender identity... Because we are lesbians.

When we walk out into the field they make faces, they call us names. It really discourages us if we hear them calling us lesbians and telling us to go home. [Spectators shout:] "Go home. Go cook food. Go cook dinner." They call us names, like "panikeke [derogatory Fijian slang denoting lesbian]." "You bunch of lesbians.”

Negative sanctions also spill into other areas of their daily life. One participant described her experiences and feelings of alienation:

Even when you finish training there would be comments coming from guys and some women. Women tell you: "You should just go home and wash the dishes, you belong in the kitchen." ... And people laugh at us when we play, when we make mistakes. Even when you are walking in town, in public places, you are trying to put your head up, but you can't, because people are looking at you in a way that says, "What are you doing? Why are you making a fool of yourself?"

Despite recent changes in public responses to women's rugby (see below), women rugby players continue to incur intense societal condemnation. Yet they continue to play, not only because of their love of the game and desire to realise their athletic potential, but because of a personal and political significance that the act holds for them, which we explore below.

\section{Refuge, agency and resistance}

While rugby puts the players at the brunt of severe negative sanction, it also offers them a shelter from it. As a participant explained: “A lot of these girls who are gay come and play the sport because they see this sport as a kind of safe haven.” Paralleling the 
historical role of sport among lesbian athletes elsewhere (Griffin, 1998), the players, coaches and supporters (mainly the players' close friends and partners) form close-knit communities, centred around their clubs, that provide a sense of safety and compensate for the absence of institutional and family support. Here, unemployed players are assisted with their bus fares and daily sustenance. Those experiencing emotional struggle are counselled by older peers. These communities are also a critical, and sometimes the only, source of a collective sense of belonging:

Most of those girls are masculine, you know, who don't fit in. They found a place to be. We all have the same kind of way of thinking because we are boyish and all this [different]...

[Discouragement and punishment] makes them leave home. And they start to look for safe spaces to live in and to play the sport; to feel safe. And most of them say it is rugby, that's where they feel safe.

This is also one of the few spaces where the players "come out." While most lesbian athletes choose not to publicly disclose their sexuality to avoid further punishment, the "safe space" of rugby allows self-expression:

The club becomes a refuge where they [players] feel comfortable, they can be themselves, they can practice whatever sexuality, and nobody is going to say a thing. You just be yourself.

[Interviewer: "What keeps you playing?”]

I think it's not just because of the love of rugby, it's the bond that we have together. ... I think it's the space ... it's the identity. [Many players are] lesbians and they can't talk about it with anybody at home. ... This is their only place.

Furthermore, while they keep their sexual transgression concealed to the public, the players use rugby's “masculine” attributes as a medium of gender expression in a more open, bold, and notably oppositional manner. Our participants appropriate rugby as a space for exploring and somewhat defiantly flaunting their "female masculinity" (Halberstam, 1998). They embrace and capitalise on the game's "toughness", which, as Broad (2001, p. 189) points out, counters "the passivity assumed in a traditionally feminine, apologetic stance”, to freely express themselves and openly resist gender normativity. This gives them a notable sense of empowerment: 
You get to play something that allows you to express yourself... the game is awesome! Women's rugby allows you to do that.

You are free from the traditional obligations. It's breaking that stereotype about women, yes, gender stereotypes. Playing rugby gives you that freedom. You can wear shorts...They don't expect you to wear skirts! ... For most of them, it allows them to be themselves.

You get so conscious of the boys looking at you. ... All this [male attention] makes you conscious.... And that is a lot of restriction to who you are. We don't have that here [in rugby]. ... And that is a lot of freedom. ... You are at peace. You are justfree!

Contrary to the dominant popular discourse that defines Fijian women as passive victims of violence and oppression (Pacific Media Watch, 2006), Fijian women have always resisted subordination with "a long history of covert protest within women's work" (Leckie, 2002, p. 164). While professional women have engaged in political activism, grassroots women have challenged hegemonic gender structures in their various daily practices, which may not be documented or take the form of formal political action. Women claiming masculinity in rugby can be seen as one such instance of grassroots opposition.

Some observers may question if such acts of gender transgression qualify as resistance and if they indeed reinforce, rather than subvert, hegemonic masculinity. Objections may be raised that these players are " "unliberated" and (male-identified) ... as a consequence of their re-enacting a violent, aggressive, competitive sport form” (Wheatley, 1994, p. 208). But this argument presupposes a essentialist and binary position that masculinity is a natural, innate, or exclusive quality of males. As Halberstam (1998, p. 241) shows, masculine women have historically demonstrated that “masculinity does not belong to men, has not been produced only by men, and does not properly express male heterosexuality... [W] hat we call 'masculinity' has also been produced by masculine women, gender deviants, and often lesbians”.

In exploring athlete agency, we also stress the importance of recognising that oppositional intentionality is expressed in myriad ways across communities and cultures, 
which does not necessarily take the form of an explicit political rhetoric. While most Fijian women rugby players are not formally involved in political activism ${ }^{4}$, they clearly see political intent in their own rugby practice:

[Interviewer: "Why do you play rugby?”]

It's because it's a man's game. ... It pushes me every day because I think that ... as a woman I have to stand up to this and reclaim the world.... Before we go to the field to play rugby, we remind ourselves ... that this is a man's game. ... We too can play the game and we can shut them off by showing them how we play.

Most of the girls ... are not used to the crowd. I always tell them: "The crowd is there. Shut your ears [to the jeering] and just play. And tell those people that we can play rugby." Yes. That's how I always feel when I play in [front of] a big crowd. I feel motivated. Like I have to tell these people watching that women too can play rugby!

Playing rugby is an act of defiance for these athletes. Indeed, reminiscent of Halberstam’s (1998, p. 167) “raging bull,” some referred to the expression of anger as an important part of their motivation. One observed: "If you hear [some players'] stories, they're very, very sad... Watch them play. That's where their anger, their frustration and everything - they chuck it away.” Another described her own fury towards the injustice that she seeks to fight through rugby:

Participant: It's not only because I want to play the sport.... This [rugby] is where some of us express our feelings, out on the field.

Interviewer: What sort of feelings do you express on the field?

Participant: Anger... [Towards] All these comments from everybody calling us names. That's where we prove them wrong, out on the field. [I play] to win the game, and, not only that, if they know I am lesbian, I want to show I'm a lesbian and I can also play the sport.

These rugby players, if not in a formal political fashion, daily challenge gender essentialism and embody the plasticity of gender. Their resistance is both overt and covert. It is overt as they openly and proudly display gender variance; it is covert, as the defiance is not always verbalised or formalised - it is largely an unspoken, performative resistance. 


\section{Accommodation and negotiation}

However, rugby is not a monolithic space constituted by either domination or resistance. It is mediated by competing and conflicting forces, where athletes negotiate an array of circumstances, agendas and interests, and where at times they are co-opted and their resistance curtailed by malestream rugby. First, their resistance is time- and space-bound. As pointed out by Wheatley (1994, p. 208), women rugby players' gender/sexual transgression is "largely temporal. Restraints imposed by time and space clearly limit the visibility of their resistant style. Off the field and after the party, many of the women return to the 'real world'.” Many athletes who live with their families have no choice but to conceal what may be central to their sense of self while at home:

Mere is that way [masculine] on and off the field. But Mere can't say that she's lesbian. In 20xx, her uncle found out that she was lesbian.... She got chased from her home and went to live with Ana. She couldn't stay there anymore and went back and asked for forgiveness. [Today] Even though she goes to the plantation and does men's work, she still can't [be open with her gender and sexual identity].

Your gay life is only within the interior of certain things. For the majority of the girls who play rugby, their rugby friends are the only ones that know. It's not known by everybody. Even their parents don't know about it.

Second, open resistance is limited to gender, as against sexual, transgression. Athletes embrace and display their masculinity in an open and bold manner, especially on the field and in their rugby communities; yet few publicly disclose their sexuality. Similarly, all but one women's rugby club avoid open discussion of sexuality. The "out” and “cocky” queer resistance that Broad (2001, p. 195) observes among American women rugby players is not possible in a socio-cultural context where non-normative sexuality invites real threats to physical safety and social survival. Even as they refuse to comply with heterosexism, most lesbian athletes do so in a carefully covert manner.

Third, the athletes' resistance is circumscribed by powerful institutional pressures that they must engage with if they are to keep their sport alive. To secure societal and institutional acceptance and access institutional resources, some women's rugby leaders have encouraged public displays of compliance with gender norms. They have made an attempt (although it did not eventuate) to enforce a "feminine" dress and behavioral 
code to enhance the socio-cultural legitimacy of their community. Such compromise, like that of the UK gay rugby club studied by Price and Parker (2003, p. 121), promotes "the image ... of normality and respectability with the club distancing itself from radical political activism.”

Consequently, their resistance is not manifested in formal political activism, as noted above. The players and officials prioritise the immediate goals of improving the standard of the game, increasing the player base and game opportunities, securing institutional and public support, and protecting their space for self-expression and mutual bonding. Most avoid open discussion of sexuality and seek to remove the automatic association between women's rugby and lesbianism. In short, athletes and their leaders negotiate varied interests and agendas under specific historical, political and socio-cultural conditions and constraints. The end result is a subtle and complex mix of covert and overt resistance, accommodation and compromise.

\section{Theoretical reflections on the findings: ongoing hegemonic struggle}

Emerging from these athletes' voices is a notable characteristic of women's rugby in Fiji as a site of ongoing hegemonic struggle. The participants' accounts illustrate a complex interplay between a hegemonic gender/sexual regime and athletes' agency, as well as the ways in which individual athletes negotiate this entanglement to resist and challenge, yet at times also accommodate and manage, the existing relations of power. Rugby here constitutes “a battle field ... a continuous struggle” (Mouffe, 1979, p. 185).

Consequently, athletes are also engaged in their own counter-hegemonic struggle. By negotiating and balancing the need for recognition in mainstream rugby and the pursuit of their own needs and interests, by resolutely improving the standard of their game, by seeking greater public recognition, etc., athletes are engaged in counter-hegemonic struggle to effect a shift in the dominant rugby discourse. Indeed, they have made some tentative yet significant victories in this struggle. The Fijiana have recently made monumental achievements, such as winning the Gold at the 2011Pacific Games, and qualifying for the 2013 Rugby World Cup Sevens and for the 2014-15 World Rugby Women's Sevens Series. There are indications that such emerging prominence may be starting to wane the hegemonic articulation between masculine power, rugby and ethno-national pride especially over the last few years. In 2014, a national television channel broadcasted the women's games of a domestic sevens rugby tournament for the first time and a national newspaper ran its first front-page coverage of the Fijiana's 
international success. The FRU chairman recently made a notably laudatory comment that the Fijiana "have toiled on quietly to ... be fine ambassadors of FRU and Fiji... There is much to learn from them. Their selfless desire to represent the country is refreshing and uplifting” (Fijilive, 2014). An alternative discourse is also emerging in wider society. The FWRU President notes that following a recent television interview, she was approached by members of the public shaking her hand and saying: "Thank you so much for talking on TV. We can see you guys are going through a lot.” Some participants also added that in the context of the Fijiana's growing public profile, their families, who had been fiercely opposed to their rugby career, became supportive since they joined the national squad.

As Gramsci (1971, p. 195) explains, the rise of a hegemonic/counter-hegemonic discourse is "a process of differentiation and change in the relative weight that the elements of the old ideologies used to possess. What was previously secondary and subordinate, or even incidental ... becomes the nucleus of a new ideological and theoretical complex.” Williams (1977, p. 122) extends this by identifying the "dominant”, "residual” and "emergent” elements of a cultural process and their dynamic interrelations. In the case of women's rugby in Fiji, we detect an "emergent" cultural shift, whereby the nationalist discourse may be strategically articulated with women's rugby, while the masculinist, traditionalist discourse may be weakened in its significance (and become "residual") in the hegemonic alignment. That is, a counter-hegemony may be achieved through appropriation of the hegemonic articulation of rugby with national identity and aspirations. In this "emergent" cultural discourse, women's rugby, by putting “Fiji on the world map”, begins to assume an alternative meaning as "the pride of our nation", not a desecration of ethno-national identity. Indeed, the embryonic shift has been an emotive experience for those who are personally involved:

One of the girls, if you look at her, she's a boy. But she's a girl. And her dad came to watch [her play] for the first time. She scored the winning try. He shook everybody's hand in the grandstand and then he sat down and started crying. "All of these years, I've heard about her playing, but I've never bothered to support her, to watch her." He shed tears for his daughter.

Continued international success may prompt a further decisive shift in the hegemonic configuration. The athletes remain consciously and resolutely dedicated to this goal. 
They are, then, far from helpless victims of a supreme gender/sexual regime. They are dynamic agents of an ongoing hegemonic struggle.

\section{Conclusions}

The foregoing discussion has explored the relationship between sport, gender, sexuality and power in the context of women's rugby in Fiji. We argued that the nexus between sport, gender and sexuality in Fiji is intersected by postcoloniality. In Fiji, the gendered nature of rugby is accorded primary significance as an expression of ethno-national pride and challenge to postcolonial marginality. The hegemonic articulation of gender and hetero-normativity with rugby is further consolidated by anti-colonial nationalism, giving it greater moral and cultural legitimacy and making it doubly difficult for women to challenge. The hegemonic articulation operates to suppress women's opposition through the powerful appeal of the nationalist/traditionalist discourse.

This means that women playing rugby incur doubly severe sanctions. Despite some recent improvement in institutional and public responses, the athletes have struggled immensely to secure financial, technical or emotional support from their families, rugby bodies and the general public. Furthermore, many have experienced verbal, psychological and/or physical punishment and abuse in their homes and communities. Indeed, ostracism has led some to leave their families and seek alternative (often austere) housing arrangements.

In the face of such unforgiving adversities, the athletes continue to play rugby. Most players are not involved in formal political activity and are largely unemployed with limited formal education. Many have been ostracised by their own families and communities. Thus they form one of the most disenfranchised social groups in Fiji. In this context, rugby clubs provide a much-needed sense of security, community and emotional connection, which enables them to realise their athletic potential, express their masculinity (and their sexuality in a covert manner) and thereby resist the powerful forces of gender and hetero-normativity within the limits of the existing personal, socio-cultural and institutional circumstances. The clubs constitute a critical (and often the only!) space for collective identification, emotional (and sometimes physical and financial) shelter, empowerment and grassroots political practices in a male-dominant world.

The players are also at times co-opted and their resistance circumscribed by powerful 
pressures from families, communities and malestream rugby. Their resistance is timeand space-bound, more often covert, and not expressed as formal activism. Their leaders have (at least tentatively) sought to accommodate some gender norms to secure a degree of socio-cultural and institutional legitimacy. The players' responses are, then, a complex mesh of both apologetic and unapologetic behaviors as well as "in-betweens." The existing predominantly Western literature tends to view compromise and accommodation as the limits to athlete resistance. Anything less than conscious, frontal attack on dominant sport structures guided by a formal political rhetoric tends to be questioned of its transformative efficacy. However, our participants highlight the importance of appreciating the extent of the physical, social and emotional harm that overt resistance invites in a postcolonial context where the hegemonic rugby-masculinity-heterosexism complex is invested with passionate traditionalist, anticolonial sentiments. In this setting, strategically managing and negotiating hegemonic pressures is an integral part of their ongoing struggle, not its closure. They negotiate a complex array of circumstances, agendas and interests in a creative and resilient manner as they steadily, if covertly, chip away at the hegemonic gender block.

By their acts of overt and covert resistance and negotiation, the players are engaged in their own counter-hegemonic struggle to initiate a shift in the dominant rugby discourse. Following the Fijiana's recent international successes, greater acceptance by and prominence in mainstream rugby may be creating a transformative fissure in the athletic gender regime, which may grow in its counter-hegemonic impact and scope as it expands into an alternative rugby discourse. Women's rugby may successfully align itself with the hegemonic articulation between rugby and ethno-national identity, while the masculinist, traditionalist discourse may possibly dampen in its significance. Rugby thus constitutes "a political terrain characterised by internal contradiction and paradox that leave room for the play of oppositional meanings, and potentially for the organisation of collective resistance and institutional change” (Messner, 1995, p. 225). The case of Fijian women rugby players illuminates the interplay between a multiplicity of power relations in sport in a postcolonial society and the resilience with which the athletes negotiate and respond to them, as well as the dynamic nature and the transformative potential of their everyday practices.

Notes 
${ }^{1}$ Since Fiji's women's rugby community is small, with only five major clubs, all women’s rugby officials (coaches, trainers, club administrators, etc.) are either current or former players themselves, who come from similar backgrounds to the current players, and their roles as officials (except for the national coach) are unpaid and voluntary.

2 The Maori are the indigenous Polynesian people of New Zealand, who share similar sociocultural traditions, colonial experience, and postcolonial challenges with Fijians and other Pacific (especially Polynesian) islanders.

${ }^{3}$ The FRU officially supports women's rugby, provides a national coach and facilitates national team tours. In 2012, World Rugby created the position of Oceania Women’s Rugby Development Officer (based at the FRU).

${ }^{4}$ Only one club is organised and funded by a lesbian feminist organisation.

\section{References}

Adjepong, A. (2015) 'We're, like, a cute rugby team': how whiteness and heterosexuality shape women's sense of belonging in rugby. International Review for the Sociology of Sport. DOI: 10.1177/1012690215584092.

Asian Development Bank (2006) Republic of the Fiji Islands Country Gender Assessment. Pacific Regional Department and Regional and Sustainable Development Department, Asian Development Bank, March 2006.

Birrell S and Cole C L (1990) Double Fault: Renee Richards and the Construction and Naturalisation of Difference. Sociology of Sport Journal 7(1): 1-21.

Bairner A (2001) Sport, Nationalism, and Globalisation: European and North American Perspectives. Albany, NY: State University of New York Press.

Broad KL (2001) The Gendered Unapologetic: Queer Resistance in Women’s Sports. Sociology of Sport Journal 18(2), 182-204.

Butt J and Molnar G (2009) Involuntary Career Termination in Sport: A Case Study of Error! Main Document Only.the Process of Structurally Induced Failure. Sport in Society 12(2): 236-252.

Cahn, SK (1994) Coming on Strong: Gender and Sexuality in Twentieth-Century Women's Sport. Cambridge, Massachusetts: Harvard University Press. 
Carle A and Nauright N (1999) A Man’s Game? Women Playing Rugby Union in Australia. Football Studies 2(1): 55-73.

Caudwell J (1999) Women's Football in the United Kingdom: Theorizing Gender and Unpacking the Butch Lesbian Image. Journal of Sport and Social Issues 23(4): 390 402.

Chase LF (2006) (Un)disciplined bodies: A Faucauldian analysis of women's rugby. Sociology of Sport Journal 23(1): 229-247.

dé Ishtar Z (1994) The Spirit of Resistance. In: dé Ishtar Z (ed) Daughters of the Pacific. North Melbourne: Spinfex Press, pp. 217-232.

Doucet A and Mauthner NS (2006) Feminist methodologies and epistemologies. In: Clifton DB and Dennis LP (eds) Handbook of 21st Century Sociology. Thousand Oaks, CA: Sage, pp. 36-42.

Dunning E (1994) Sport as a Male Preserve: Notes on the Social Sources of Masculine Identity and its Transformations. In: Birrel S and Cole CL (eds) Women, Sport, and Culture. Champaign, Illinoi: Human Kinetics, pp. 163-179.

Ezzell MB (2009) 'Barbie dolls’ on the pitch: identity work, defensive othering, and inequality in women's rugby. Social Problems 56 (1): 111-131.

Fallon MA and Jome LM (2007) An exploration of gender-role expectations and conflict among women rugby players. Psychology of Women Quarterly 31(3): 311-321.

Felshin J (1974) The Triple Option ... for Women in Sport. Quest 21(1): 36-40.

Field M (2015) Bainimarama asserts all Fijians have right to watch rugby free. Rugby Heaven. Available online [http://www.stuff.co.nz/sport/rugby/international/65293542/bainimarama-asserts-all-fiji ans-have-right-to-watch-rugby-free]. Retrieved 18 May 2015. 
Fiji Bureau of Statistics (2015a) Fiji Statistics at a Glance. Available at: http://www.statsfiji.gov.fj/(accessed 4 March 2015).

Fiji Bureau of Statistics (2015b) Poverty Indicators. Available at http://www.spc.int/prism/fjtest/Social/poverty_indicators.htm (accessed 4 March 2015).

Fiji Rugby Union (2011) The Fiji Rugby Union. Available at: http://www.fijirugby.com/pages.cfm/about-union/(accessed October 23, 2011).

Fiji Women’s Crisis Centre (2013) Somebody's Life, Everybody's Business! National Research on Women's Health and Life Experiences in Fiji (2010/2011): A survey exploring the prevalence, incidence and attitudes to intimate partner violence in Fiji. Suva, Fiji.

Fijilive (2014) Rio is the next step for Fijiana: FRU. Fijilive. 15 September, 2014. Available at: http://fijilive.com/sports/rugby/news/2014/09/rio-is-next-stop-for-fijiana-fru/35492.Fijil ive (accessed 15 January 2015).

Gill F (2007) “Violent” femininity: Women rugby players and gender negotiation. Women's Studies International Forum 30(5): 416- 426.

Gramsci A (1971) Selections from the Prison Notebooks (eds and trans. Q Hoare and GN Smith). New York: International Publishers.

Griffin P (1998) Strong Women, Deep Closets: Lesbians and Homophobia in Sport. Champaign. Illinoi: Human Kinetics.

Halberstam J (1998) Female Masculinity. Durham: Duke University Press.

Hardy, E. (2014) The female 'apologetic' behaviour within Canadian women's rugby: athlete perceptions and media influences. Sport in Society 18 (2): 155-167.

Hargreaves J (1986) Where's the Virtue? Where's the Grace? A Discussion of the Social Production of Gender Relations in and through Sport. Theory, Culture \& Society 3(1): 
109-121.

Hargreaves J (1997) Women's Boxing and Related Activities: Introducing Images and Meanings. Body \& Society 3(4): 33-49.

Hau'ofa E (1993) Our sea of islands. In: Waddell E, Naidu V and Hau'ofa E (eds) A New Oceania: Rediscovering Our Sea of Islands. Suva, Fiji: University of the South Pacific, pp. 2-16.

Hoskins TKC (2000) In the Interests of Māori Women? Discourses of Reclamation. In: Jones A, Herda P and Suaalii TM (eds) Bitter Sweet: Indigenous Women in the Pacific. Dunedin: University of Otago Press, pp. 33-48.

International Rugby Board (2012) Fiji. Available at:

http://www.irb.com/unions/union¹/411000030/index.html (accessed 15 January 2013).

Jalal P I (2002) Gender Issues in post coup d'etat Fiji: Snapshots from the Fiji Islands (a short story of life in the feminist trenches). Keynote speech at Townsville International Women's Conference: Poverty, Violence and Women's Rights ... Setting a Global Agenda. 3-7 July 2002, James Cook University.

Johnson J and Vithal P (2015) "Prejudice in Paradise": An Examination of Old-Fashioned and Modern Homonegativity in a Sample of Fijians. Public seminar at the University of the South Pacific, 13 March, 2015.

Kanemasu Y and Molnar G (2013a) Collective Identity and Contested Allegiance: A Case of Migrant Professional Fijian Rugby Players. Sport in Society 16(7): 863-882.

Kanemasu Y and Molnar G (2013b) Problematizing the dominant: the emergence of alternative cultural voices in Fiji rugby. Asia Pacific Journal of Sport and Social Science 2(1): 14-30.

Kanemasu Y and Molnar G (2013c) Pride of the People: Fijian Rugby Labour Migration and Collective Identity. International Review for the Sociology of Sport 48(6): 720-735. 
Molnar, G. and Kanemasu, Y. (2014) "Playing on the global periphery: Social scientific explorations of rugby in the Pacific Islands." Asia Pacific Journal of Sport and Social Science, 3 (3): 175-185.

Kleindienst-Cachay C and Heckemeyer K (2008) Women in Male Domains of Sport. International Journal of Eastern Sports \& Physical Education 6(1): 14-37.

Leckie J (2002) The complexities of women's agency in Fiji. In: Yeoh B S A, Teo P and Huang S (eds) Gender Politics in the Asia-Pacific Region. London: Routledge, pp. 156-180.

Mennesson C (2000) "Hard” women and "soft" women: The social construction of identities among female boxers. International Review for the Sociology of Sport 35(1), 21-33.

Messner M (1988) Sports and male domination: The female athlete as contested ideological terrain. Sociology of Sport Journal 5(3): 197-211.

McCormick JP (2013) Fiji: LGBT rights campaigners say discrimination remains a major issue. Pink News. 16 May, 2013. Available at:

6/fiji-lgbt-rights-campaigners-say-discrimination-remains-a-major-issue/ (accessed 16 March, 2015).

Mohanty CT (1988) Under Western Eyes: Feminist Scholarship and Colonial Discourses. Feminist Review 30: 61-88.

Mouffe C (1979) Hegemony and Ideology in Gramsci. In: Mouffe C (ed) Gramsci and Marxist Theory. London: Routledge and Kegan Paul, pp. 168-204.

Narawa E (2013) Playing for our heroes. Fiji Times Online. 12 June, 2013. Available at: http://www.fijitimes.com/story.aspx?id=236666 (accessed 16 March 2015).

Nasokia W (2014) Fiji Airways Backs Junior Players. Fiji Sun Online. 3 December. Available at: http://fijisun.com.fj/2014/12/03/fiji-airways-backs-junior-players/ (accessed 11 March 2015). 
Nauright J and Chandler TJL (1996) Making Men: Rugby and Masculine Identity. Oxon, Oxfordshire: Routledge.

Pacific Media Watch (2006) Who Makes The News? Women as Victims in Fiji Media. Scoop Independent News, 20 February, 2006. Available at: http://www.scoop.co.nz/stories/WO0602/S00322.htm (accessed 18 March, 2015).

Price M and Parker A (2003) Sport, Sexuality, and the gender order: Amateur Rugby Union, Gay Men, and Social Exclusion. Sociology of Sport Journal 20 (1): 108- 126.

Ratuva A (2015) Be Proud Of Our Boys. Fiji Sun Online. 13 February 2015. Available at: http://fijisun.com.fj/2015/02/13/be-proud-of-our-boys/ (accessed 11 March, 2015).

Reinharz S (1992) Feminist Methods in Social Research. New York: Oxford University Press.

Sabo D (1993) Psychosocial Impacts of Athletic Participation on American Women: Facts and Fables. In: Eitzen DS (ed) Sport in Contemporary Society: An Anthology. New York: St. Martin’s Press, pp. 374-387.

Scraton S, Fasting K, Pfister G and Bunuel A (1999) It's still a man's game? The experiences of top-level European women footballers. International Review for the Sociology of Sport 34 (2): 99-11.

Spivak G (1988) Can the subaltern speak? In: Nelson C and Grossberg L (eds) Marxism and the Interpretation of Culture. Urbana: University of Illinois Press, pp. 271-313.

Sprague J (2005) Feminist Methodologies for Critical Researchers: Bridging Differences. Walnut Creek, California: AltaMira Press.

Teaiwa TK (2005) Articulated cultures: Militarism and masculinities in Fiji during the mid 1990s. Fijian Studies 3 (2): 201-222.

Tovia K (2014) Making sense of the everyday women rugby player. Unpublished MA 
Thesis. Victoria University, New Zealand.

Watson T (1987) Women Athletes and Athletic Women: The Dilemmas and Contradictions of Managing Incongruent Identities. Sociological Inquiry 57(4): 431-446.

Wheatley EE (1994) Subcultural subversions: Comparing discourses on sexuality in men's and women's rugby songs. In Birrell S and Cole C (eds) Women, sport and culture. Champaign: Human Kinetics, pp. 193-211.

World Economic Forum (2013) The Global Gender Gap Report 2013. Cologny/Geneva Switzerland.

World Rugby (2007) Fiji form Women's Rugby Union. World Rugby 12 November, 2007. Available at: http://www.worldrugby.org/news/22540 (accessed 16 March 2015).

Wright J and Clark G (1999) Sport, the Media and the Construction of Compulsory Heterosexuality: A case study of women's rugby union. International Review for the Sociology of Sport 34(3): 227-243. 